\title{
CERVANTES EN BUSCA DE UNA PASTORAL AUTÉNTICA
}

\section{La Galatea, pastoral amorosa no consumada}

Como todas las novelas pastoriles, La Galatea de Cervantes es básicamente una anatomía del amor, un medio de ficción para expresar reflexiones y consideraciones sobre los misterios, los éxtasis y los estragos del amor ${ }^{1}$. Como todas las obras de este tipo, coloca al lector en un ambiente remoto, como de laboratorio, en el que los más puros sentimientos amorosos - amor, odio, celos, desesperación, frustración, melancolía, esperanza, exaltaciónpueden mostrarse y analizarse sin interferencias debidas a las complejidades del mundo real, con sus ineludibles características materiales, biológicas, económicas o sociales. Al hacerlo así, revela sus relaciones íntimas con la lírica amatoria de la tradición cortesana y petrarquista -en especial con su "registro sombrío" de sufrimiento y frustración-, cuyos tropos e invenciones amorosas centrales parece estar " actuando" o literalizando en sus argumentos, escenarios y agentes estilizados. La Galatea de Cervantes, con sus numerosas piezas poéticas de forma fija, sus escenas de amormuerte, su narración fragmentada y espacializada, así como su reiterado homenaje a la poesía y a los poetas del petrarquismo, es un ejemplo particularmente notable de esas relaciones ${ }^{2}$. Las ac-

${ }^{1}$ El mejor estudio de La Galatea en su aspecto convencional es el de J. LoWE, "The Cuestión de Amor and the structure of Cervantes' Galatea", BHS, 43 (1966), 98-108. Véanse también F. López Estrada, La "Galatea"' de Cervantes: estudio crítico, La Laguna de Tenerife, 1948, y B. WARDROPPER, "The Diana of Montemayor: Revaluation and interpretation", SPh, 48 (1951), 126-144.

${ }^{2}$ Para apreciar el poder generador de la lírica convencional en la elaboración de la primera obra importante de Cervantes, basta examinar las impresionantes transposiciones narrativas de sus asociaciones metafóricas entre amor y muerte, y echar una ojeada a los versos del poeta cuya obra alaba en el largo 
tualizaciones narrativas de las categorías codificadas de la experiencia amatoria producen -además de los extraños efectos de implausibilidad que resultan de un lenguaje puramente literario vuelto arbitrariamente referencial - una curiosa mezcla de intemporalidad e intensidad líricas con sucesión narrativa, un movimiento incesante hacia una meta que rebasa el momento presente de plenitud, una mezcla desorientadora que para los lectores modernos (y se diría que también para los contemporáneos, como el propio Cervantes) parece bastante precaria, aun en la mejor de las novelas ${ }^{3}$. La pequeña pastoral burlesca de Sancho Panza en La

encomio del último libro de La Galatea ("Canto de Calíope"). El más ilustre de los descendientes modernos de Homero, Virgilio y Petrarca es Francisco de Figueroa, cuyos exquisitos poemas de amor le valieron en Italia el sobrenombre de "el divino Figueroa", título que antes sólo se había dado a Petrarca, según su biógrafo (véase el prólogo de A. González Palencia a las Poesías de Francisco de Figueroa, Madrid, 1943). La poesía de este maestro de "la sagrada honrosa ciencia de Febo" y de "la cortesana discreción" ( La Galatea, ed. J. B. Avalle-Arce, Madrid, 1961, t. 2, p. 224; a esta edición remitirán todas las citas) representa la articulación más extrema de lo que podríamos llamar el registro sombrío del modo petrarquista: una insistencia en las emociones violentas e incontrolables, en la enajenación del objeto femenino del deseo, en el sufrimiento, la esclavización, la idolatría y la autodestrucción. En la "Égloga pastoril", su poema más famoso, el pastor Tirsi medita en "los misterios" de la cruel Venus "que desiguales ánimas y formas/ se deleita enlazar con crudo juego" (Poesías, pp. 73-77), llora toda la noche el rechazo de Daphne, queda desfigurado, busca la muerte en la soledad, habla del cuchillo con que piensa suicidarse y escribe la historia de sus sufrimientos en el tronco de un árbol.

${ }^{3}$ La novela pastoril, según T. ROSENMEYER (The green cabinet, Berkeley, 1969, pp. 95-97), nació como una forma que, en busca de un efecto estático, desarrolló un sistema para alargar "the present moment of fullness" por medio de las repeticiones, el eco y los motivos musicales. Si así es, podría sospecharse que la introducción del movimiento narrativo tendiente a una meta, aun cuando esté " destemporalizado" por la fragmentación, el entrelazamiento y la repetición analógica, como ocurre en la obra francamente experimental de Cervantes, es un procedimiento esencialmente reñido con su realidad más profunda. Sobre la extrañeza fundamental que resulta de la aprehensión de imágenes líricas en términos referenciales, véase $\mathrm{T}$. Todorov, The fantastic: A structural approach to literary genre, tr. R. Howard, Ithaca, 1975, p. 60. Sin embargo, como ha mostrado hábilmente $\mathrm{R}$. ColIE, mediante la literalización ("desmetaforización") dramática de las invenciones habituales del "protected and enclosed garden of love-lyrics", un Shakespeare puede lograr un análisis penetrante de la problemática de la experiencia amorosa codificada u oculta en su sistema literario (véase su interpretación de Otelo en Shakespeare's living art, Princeton, 1974, pp. 135-167). Se podría decir, además, que en términos generales la novela pastoril del siglo XVI, a pesar de su carácter manierista, 
Torralba, narración desintegrada que muestra, como en teatro de títeres, las huidas y persecuciones de pastores y pastoras que aman y odian - un "caso de amor" basado en el tema familiar de la casuística pastoril, los efectos y los usos de los celos-, y trescientas desventuradas cabras que nunca logran atravesar un río, señala a mi parecer, y de manera muy efectiva, algunas de las rarezas de este tipo de narración, así como su fragilidad fundamental ${ }^{4}$.

Lo que, en mi opinión, hace que La Galatea de Cervantes, aunque menos lograda como ficción, sea más interesante que sus modelos principales, no es el esfuerzo evidente del autor por indagar más a fondo en la problemática de la experiencia amorosa, ni su ambiciosa experimentación formal, sino las tensiones presentes en la obra. Estas tensiones indicarían que Cervantes estaba separado de la experiencia y del discurso amoroso que caracterizan a sus modelos, y a la vez prefiguran la crítica a fondo de La Galatea que encontramos unos veinte años después en el Quijote, y la búsqueda subsecuente que hace el autor de otra forma de pastoral y de otra experiencia del amor.

Las fuentes de las tensiones de La Galatea son múltiples, y muy complejas ${ }^{5}$. En este artículo me limito a dos que me parecen fundamentales: la primera es el tratamiento que da Cervantes a su heroína, descendiente de las dos Dianas, ese sólido díptico que,

clasicista, aristocrático y hermético, representaba un esfuerzo serio por sacar a la literatura amorosa de ese claustrofóbico jardín. R. O. Jones, "Bembo, Gil Polo, and Garcilaso: Three accounts of love', $R L C, 40$ (1966), 526-540, dice que la lírica amorosa cortesana es en la mayoría de los casos una poesía de cortejo, no consumación, suspensión y sufrimiento; en tal caso, y dado el carácter esencialmente teleológico del género narrativo, el proyecto de narrativizar sus conceptos podría indicar un deseo de superar las limitaciones de esa poesía y de su concepción del amor. Ese deseo estaría en armonía con un intento general, en la vida cultural y social del siglo XVI -en la que se señalan, por una parte, los tratados humanísticos sobre el matrimonio y, por la otra, las filosofías amorosas neoplatónicas, a las que tanto debía la novela pastoril-, de dignificar el amor humano y su posibilidad de realización en este mundo.

${ }^{4}$ El ingenioso hidalgo don Quijote de la Mancha, ed. L. A. Murillo, Madrid, 1978 , t. 1, cap. 20; a esta edición del Quijote remitirán todas las citas.

${ }^{5}$ El estudio fundamental sobre las complejidades de $\mathrm{La}$ Galatea que apuntan al arte novelístico del Quijote es el de J. B. Avalle-ArCe, La novela pastoril española, Madrid, 1959, cap. 8. Las tensiones que me interesan -centradas en el amor y la naturaleza de la mujer- pueden llevar a conclusiones perfectamente compatibles con las de Avalle-Arce sobre la evolución de Cervantes como escritor. 
en palabras de A. Solé-Leris, inició "the great vogue of Spanish pastoral noveis of the Golden Age"6; la segunda, las turbias relaciones que hay entre las filosofías amatorias centrales y la narración que pretende ejemplificarlas o manifestarlas. Me atrevo a sugerir que $L a$ Galatea, en su no acabamiento, revela el fracaso de Cervantes en su doble empeño: encontrar una voz para su heroína y conseguir una narración de plenitud amorosa. A pesar del éxito y del prestigio de sus modelos, es obvio que Cervantes era incapaz de recurrir a los arbitrarios artificios narrativos de conclusión de Montemayor y Gil Polo, y es posible que los haya considerado como evasiones frente al misterio central del amor - la reunión de un hombre y una mujer reales, de carne y hueso, en las complejas circunstancias de la vida real. Viendo el asunto desde otra perspectiva, diría que Cervantes se topó con ciertas limitaciones en las posibilidades que le ofrecía el sistema literario heredado, que tan admirablemente acorde parecía con sus aspiraciones de poeta petrarquista entre los descendientes cortesanos de Garcilaso.

La inminente desaparición de Galatea al final de la novela y la movilización resultante de los pastores, preparados para un acto de violencia que amenaza la existencia misma del mundo pastoril, pueden significar, en un nivel más profundo, qué realmente no hay cabida para ese personaje y sus anhelos eróticos en el paisaje amatorio de Arcadia. En el debate sobre el amor, hacia la mitad de la obra, sólo Galatea y la aún más enigmática Florisa se encuentran espiritualmente excluidas, pues hasta ese momento no había tomado cuenta el Amor "de sus hermosos y rebeldes pechos" (II, 57). Sólo ellas, entre tantos pastores, son ignorantes de los misterios, los enredos y los tormentos enumerados por Lenio y Tirsi. No han experimentado ninguno "de los efectos de amor [...] en sus libres voluntades". La inminente desaparición de Galatea en la conclusión es altamente sugerente, pero su aparición inicial es igualmente misteriosa, y mucho más reveladora.

$\mathrm{Al}$ comienzo de la novela Galatea se presenta, naturalmente, como una mujer bellísima, pero lo que más impresiona en la escena de su aparición es que está decidida a escapar de los enredos retóricos del narrador y de los personajes y de la idolátrica mirada de sus enamorados proyectada por esa retórica. La escena em-

${ }^{6}$ The Spanish pastoral novel, Boston, 1980, p. 68. 
pieza con la descripción del amanecer en boca del narrador - "ya la blanca aurora dejaba el lecho del celoso marido y comenzaba a dar muestras del verdadero día"' $(\mathrm{I}, 54)$. Elicio y Erastro llevan sus ovejas por una barranca, oyen el sonido de una zampoña, alzan la mirada y distinguen las formas blancas de unas ovejas en la cumbre de una colina y "luego tras ellas Galatea". Es como si la aparición de la pastora desplazara la salida del sol. El narrador entra de lleno en la descripción retórica: imposible retratar la belleza de la pastora; el sol, envidioso de su larga cabellera movida por el viento, ha intentado herirla con sus rayos y robar su luz, pero en vano, porque el deslumbrante resplandor de sus crenchas crea en realidad un nuevo sol. Si en los paralelismos visuales de la descripción el sol se ve primero desplazado delicadamente por la auténtica seguidora de la Aurora, ahora es vencido decididamente por la doncella que, fiel a las hipérboles convencionales del modo petrarquista, se convierte en sol. Los dos pastores quedan mudos, con la mirada clavada en el ídolo. En este momento se podría llegar a la conclusión de que la escena narrada representa el acabamiento de un cuadro cuyo marco ha dado Cervantes en los poemas que están al comienzo de la obra -el doblete de queja y obsesión amorosa y los versos amebeos de adoración que cantan los enamorados de Galatea. Con estas composiciones simétricas y su concentrada articulación de conceptos e hipérboles petrarquistas empieza ahí mismo un conocido movimiento pastoril hacia lo estático y el control de la emoción violenta por medio de la estilización. Pero el movimiento se ve inesperadamente interrumpido en el momento preciso en que la figura central de esa exquisita imagen (y el referente de la intensa figuración) está a punto de ocupar su lugar en ella. Galatea se niega a quedar incluida en esa imagen que se está revelando. Pasa con sus ovejas al lado de los pastores, los cuales le reprochan su desdén, tan inmerecido. Ella rompe entonces el silencio, con palabras cuidadosas pero firmes. Respeta el sentimiento de sus adoradores, pero en esos momentos su intención era dirigirse a otro sitio, a otra fuente. Los pastores le dicen que es ella la dueña de sus voluntades, que lo que ella quiere es lo que ellos quieren, y que sus almas la acompañarán dondequiera que vaya, aunque sean constantemente heridos por ella; ella contesta: "tengo por ver la primera alma, y así no tengo culpa si no le he remediado a ninguna" $(I, 56)$. Al final del conceptuoso intercambio - dolores del enamorado, pérdida de su alma, heridas recibidas de la amada cruel y desdeñosa - , Galatea afirma vigorosamente su libertad. Su con- 
cisa respuesta, construida sobre la base de la antítesis enfática, muestra la firmeza de una mujer que percibe claramente que hay posibilidades de degradación en toda obediencia a las reglas y la retórica del cortejo que adoptan sus interlocutores masculinos.

-Testimonio me levantas - replicó Galatea- en decir que yo, sin armas, pues a mujeres no son concedidas, haya herido a nadie. - iAy, discreta Galatea -dijo Elicio-, cómo te burlas con lo que de mi alma sientes, a la cual invisiblemente has llagado, y no con otras armas que con las de tu hermosura! Y no me quejo yo tanto del daño que me has hecho, como de que le tengas en poco.

-En menos me tendría yo - respondió Galatea- si en más le tuviese (I, 56).

Como era de esperar, el diálogo de Galatea se centra en uno de los conceptos básicos de la tradición lírica amatoria y de las concepciones de la experiencia amorosa implícitas en ella - el alma violentamente herida, en la que queda impresa una imagen de la amada, el alma que se desprende del cuerpo, emigra al de la amada, y la acompaña adondequiera que vaya. Este concepto, que puede entenderse como una manera metafórica de dignificar la común experiencia amorosa de la obsesión, había recibido una nueva vida y una especie de sanción filosófica en las llamadas filosofías amatorias de comienzos del siglo XvI, por medio de las muy leídas exposiciones del Banquete de Platón ${ }^{7}$. Galatea, en su distanciamiento, podría servir de contraste con la dócil discípula de León Hebreo, Sofía, quien en dos de los tres Diálogos de amor expresa su perplejidad ante los misterios del alma enamorada - sus rastros de belleza divina, su capacidad de unirse con el alma del otro- pero rápidamente acepta esos misterios al serle aclarados por su maestro y enamorado, Filone ${ }^{8}$. Y La Galatea, que en su plan general es, insisto, un homenaje a las concepciones y los discursos tradicionales del amor, a menudo expresa la elevada doc-

${ }^{7}$ La descripción más famosa del fenómeno de la migración de las almas es la que aparece en las explicaciones de Pietro Bembo sobre el amor neoplatónico en la culminación del Cortegiano de Castiglione, ed. E. Bonora y P. Zoccola, Milano, 1972, p. 342. Véase también Marsilio Ficino's commentary on Plato's "Symposium", ed. \& tr. S. R. Jayne, University of Missouri, Columbia, MO, 1944, pp. 145-146. En Gli Asolani, de Bembo, la obra cuya influencia parece haber sido más decisiva en la filosofía amorosa de La Galatea, el confidente, Gisberto, dice que ese fenómeno es como el milagro de amor que supera todos los demás milagros: Opere in volgare, ed. M. Marti, Firenze, 1961, p. 78.

${ }^{8}$ Dialoghi d'amore, ed. S. Caramella, Bari, 1929, pp. 56-58, 384-391. 
trina con toda seriedad, por ejemplo en el canto amebeo con que principia la novela, en el que se idoliza a la mujer y se glorifica el sufrimiento, y que es una especie de preparación para la escena del rechazo ${ }^{9}$. Quiero subrayar esto porque me parece que el punto de vista de Galatea representa una nota subversiva, una nota de insatisfacción a la que da voz inmediatamente su autor ${ }^{10}$. Sin embargo, el aspecto más sobresaliente de la escena es que esa nota no llega a resonar. Casi de inmediato, la afirmación de independencia de Galatea es interpretada forzadamente por sus admiradores dentro de una mitología amatoria tradicional y su retórica correspondiente, como el acto de un enemigo que triunfa cruelmente de la voluntad del otro y merece ser maldecido por él. La propia Galatea, cuyo conocimiento del amor está completamente limitado por lo que ve y oye, asume el papel que le asigna esa mitología y pronuncia un soneto que es una denuncia vehemente del amor; en él se encuentran concentrados todos los conceptos tradicionales de la violencia amatoria, que la tradición petrarquista había codificado alrededor de la figura de la "desamorada": "Afuera el fuego, el hielo, la flecha/ [ . . ] que tal llama mi alma no la quiere" (I, 57). Y como si fuera a completar

9 “" . . le diera / todo cuanto en la vida me ha quedado / a Galatea, porque me volviera / el alma"; ". . como ella debe de ser diosa, / el alma querrá más que no otra cosa" ( $(1,27)$. Los demás conceptos que va a "representar" la escena siguiente aparecen claramente aquí como poesía: "me subjetaste el día / que los cabellos de oro y bella frente / miré del sol que al sol escurecía"; " ". . el sol de dos luceros, do reposa / el blando amor, y a do estaré in eterno; / la voz, cual la de Orfeo poderosa / de suspender las furias del infierno..." (I, 25-26). Véase también el poema de Timbrio, uno de los pocos enamorados felices de la novela: "Quisiérate pedir, Nísida, cuenta / de un alma que te di: ¿dónde la echaste, / o cómo, estando ausente, me sustenta? [...] / Sin alma estoy desde la vez primera / que te vi"' $(\mathrm{I}, 174)$.

${ }^{10}$ Por su parte, J. LowE, art. cit., pp. 104-105, afirma que la conducta de Galatea se debería considerar como una manera de matizar la respuesta a una "cuestión de amor" sobre lo doloroso que es el amor, cuestión planteada analíticamente por Elicio y Erastro al comienzo de la obra. En mi opinión, el aspecto más interesante de su "respuesta" es su decidido rechazo del juego analítico y de la retórica en que se funda la novela. Podríamos añadir que, aparte de sus implicaciones referentes a lo inadecuado de una concepción tradicional de la experiencia amorosa y del papel de la mujer dentro de esa experiencia, el pasaje representa uno de los primeros casos, en la escritura cervantina, del proceso que había de producir, en el Quijote, la plena emancipación de la figura humana frente a las imposiciones de los paradigmas literarios tradicionales y el descubrimiento de un nuevo tipo de espacio literario, en el cual podía hablar con su propia voz. Véase mi Cervantes and the mystery of lawlessness, Princeton, 1984, pp. 187-194. 
ese silenciamiento de Galatea y a reparar la falla momentánea del elegante artificio de su cuadro, el narrador, que parece saber poco más acerca del amor que sus lánguidos pastores, vuelve a encerrar a la doncella en la retórica petrarquista de la idolización: la "dulce armonía" de su canto puede calmar a las fieras mejor que el laúd de Orfeo o la lira de Apolo; mientras se lava la cara en el arroyo y corta flores para hacer guirnaldas que sujetarán su larga cabellera, su cara resplandece con una belleza que imita la de las tres Gracias. La imagen podría recordarnos una de las grandes representaciones pictóricas de esos mismos misterios neoplatónicos que acaba de ridiculizar, la Primavera de Botticelli ${ }^{11}$.

Cualquiera que sea ese ser interior al que Galatea quiere respetar y proteger, sentimos que quizá el narrador esté tan lejos de entender los misterios de sus silencios y sus elipsis como lo están los dos amantes deslumbrados y que, en realidad, ninguno de los tres es capaz de aceptar que el ser de ella es único; en todo caso, no más capaz que su autoritario padre, quien al concluir la obra quiere sacarla a la fuerza de su mundo arcádico falto de vida, en el que ella sólo puede existir en calidad de diosa, y escogerle un marido que la traiga a la vida al marcarla con una identidad fabricada por él.

Durante un instante encontramos en las palabras de Galatea una negación a ser cómplice de las reglas del mundo literario en que ha sido creada, el de la pastoral amatoria que, como lo ha señalado Renato Poggioli, es fundamentalmente un mundo de sueños masculino, un mundo en que se cumple el eterno deseo varonil de amar a las pastoras como si fueran duquesas y a las duquesas como si fueran pastoras, en un sueño amoroso libre de la responsabilidad natural y social de sus propios actos, un amor que no está dispuesto a aceptar plenamente las realidades de la condición sexual del ser humano, de la vida familiar y de las relaciones conyugales $^{12}$. El rechazo de Galatea podría significar que ella anhela un amor fundado en el respeto de la realidad del individuo y consciente de los peligrosos engaños que rodean a la experiencia amorosa y a las elevadas tradiciones literarias y filosóficas que los honran. En el escepticismo de Galatea respecto a las almas de los enamorados y en la insistencia en su libertad y en su propia cap. 7 .

11 Véase Edgar Wind, Pagan mysteries in the Renaissance, New York, 1968,

${ }^{12}$ The oaten flute: Essays on pastoral poetry and the pastoral ideal, Cambridge, MA, 1975 , caps. 1 y 2 . 
estima, Cervantes vislumbra un tipo de mujer, y quizá hasta la leve silueta de un ideal amoroso que habrá de desarrollar años más tarde, en forma muy eficaz, en la Preciosa de La Gitanilla. Hasta es posible que las ironías de la escena hayan sido inspiradas al autor por el recuerdo de una de las antepasadas de Preciosa, quizá la encarnación más convincente de su ideal en las filosofías amatorias del siglo xvi: la María del coloquio de Erasmo sobre el noviazgo, especialmente por su desmistificación de las filosofías amatorias de moda en las sociedades cortesanas, con su insistencia en el sufrimiento, el amor-muerte y la resurrección, las mujeres distantes y castigadoras, y el intercambio de almas de los amantes ${ }^{13}$. Sin embargo, Galatea tiene muy poco que decir o que hacer en el resto de la obra. Es claro que Cervantes todavía no tiene plena conciencia de las posibilidades de una heroína amorosa del tipo representado por la María de Erasmo, con su insistencia en el respeto de sí misma, la independencia, la lucidez, la conciencia, la moderación, la amistad, la comprensión, la correspondencia y el lazo sacramental del matrimonio cristiano. El suave distanciamiento de Galatea, quien tiene algo de la desamorada convencional y de la secuaz de Diana de la pastoral amatoria, podría ser un rasgo que apuntara tanto hacia la feroz y destructiva Marcela del Quijote como hacia la Gitanilla.

El centro doctrinario de La Galatea es el gran debate sobre el amor, escena en la cual, por cierto, Galatea se encuentra explícitamente marginada. La extensión de este debate, su seriedad filosófica, su incorporación de los escritos de teóricos del amor tan ilustres como Bembo y Equicola, y tal vez León Hebreo y Castiglione, muestran cuán ambiciosa es esta obra supuestamente inexperta de Cervantes, que, como lo dice él mismo en el prólogo, se atreve a mezclar discursos filosóficos con los habituales discursos amorosos de los pastores ${ }^{14}$.

El debate amoroso solía examinar los problemas básicos im-

${ }^{13}$ Sobre la respuesta crítica de Preciosa a la retórica amorosa que confunde a Galatea cuando entra en su obra de ficción, su formulación de una filosofía amorosa alterna, centrada en el matrimonio cristiano y la libertad individual, y las relaciones concretas entre La Gitanilla y los escritos de Erasmo sobre el amor, véase mi Cervantes and the humanist vision, Princeton, 1982, cap. 2.

${ }^{14}$ Véase F. LóPez EsTRada, op. cit., pp. 89 ss.; "La influencia italiana en La Galatea de Cervantes", CL, 4 (1952), 161-169; G. STAGG, "Plagiarism in La Galatea", FR, 6 (1959), 255-276. 
plícitos en la novela pastoril y, en concreto, las ficciones que juegan en su superficie. No es éste el momento de tratar todas las sutilezas y fuentes del diálogo. Alexander Parker ha hecho notar recientemente que en los discursos de Lenio y Tirsi se pueden encontrar "all the ideas of love held in the sixteenth century"15. Yo, sin embargo, contra lo que sostienen muchos cervantistas, quisiera afirmar que la voz que representa auténticamente la experiencia amatoria del mundo arcádico de Cervantes, aunque no necesariamente sus premisas filosóficas, es la de Lenio. Claro que Lenio es el antagonista decidido del amor en general, y su discurso pesimista repite con gran precisión el análisis que en los Asolani hace Bembo de la naturaleza destructiva del amor sensual. El amor es terrible "enigma que ninguno hay que la entienda" (II, 56); se origina a la vista de un cuerpo hermoso, y aquel de quien se apodera queda absolutamente fuera del control de la razón y del entendimiento. Atormenta a su víctima con una infinidad de deseos imposibles de cumplir, mientras ésta trata en vano de gozar algo que está más allá de sí misma y de su control; le impide comprenderse a sí misma y comprender al otro; la atrapa en ilusiones y obsesiones y la encierra en un círculo que gira sin cesar, mientras se eleva repetidamente a las más altas cumbres de la alegría, el goce y la esperanza, sólo para volver a sumirse en el temor, la frustración y la desesperanza. El enamorado vive una sombría pesadilla de angustia, celos y odio de sí mismo, es un ser dividido que se ve obligado a mirarse constantemente desde dentro y desde el punto de vista exterior de ese otro a quien desea. La "luz de la razón" es incapaz de devolver al enajenado a su verdadero ser.

En su anatomía del deseo amoroso, Lenio subraya el solipsismo y la violencia, la proliferación y la fragmentación infinitas, el movimiento fútil y obsesivo, la repetida frustración de quien quiere acercarse a la meta y objeto del amor. El deseo engendra "todas las pasiones", las perturbaciones que atormentan al alma y destruyen su tranquilidad; "del primer deseo que nace en nosotros otros mil se derivan, y éstos son en los enamorados no menos diversos que infinitos"; "todas las veces que el deseo de alguna cosa se enciende en nuestros corazones, luego nos mueve a seguirla y a buscarla, y buscándola y siguiéndola, a mil desordenados fines nos conduce" (II, 46-47). El amor es como el gusano de seda que se destruye y se ahoga dentro de su propio capu-

15 The philosophy of love in Spanish literature, Edinburgh, 1985, pp. 117-119. 
lio; es como un camino que invita, pero se estrecha y se convierte en un asfixiante callejón sin salida; es una preñez que nunca llega a su término. Recordando los conocidos infiernos amorosos de la tradición literaria medieval, Lenio compara a las víctimas del amor con Ixión que gira en su rueda de fuego, con Sísifo que empuja interminablemente su piedra, con Tántalo que trata de alcanzar el objeto eternamente inalcanzable.

Tirsi rechaza la diatriba de Lenio con una visión mucho más optimista del amor. Haciéndose eco a su vez de los teóricos neoplatónicos, argumenta que el amor es el deseo de lo bueno y de lo hermoso, un deseo que implica la comprensión racional de su objeto y que puede ser guiado por la razón, y, con ella, conservarse puro de los bajos deseos y las ilusiones que éstos alimentan. Un amor tal ordenará las pasiones, engendrará las virtudes de la templanza, la prudencia, la fortaleza y la justicia, y encontrará su gozoso cumplimiento en la unión de dos almas, dos voluntades, en el matrimonio cristiano y la procreación santificada.

A la acumulación de imágenes de circunvolución, desorden y deseo frustrado de Lenio responde la insistencia de Tirsi en las imágenes de consumación, iluminación, plenitud y acabamiento. El enamorado racional, que ve las cosas con claridad, gozará de una unión perfecta y por la "escala de amor" ascenderá a la visión de la "dulce región del cielo sancto". El amor es la "cumbre" donde "lo intricado se allana", el "norte" que guía al hombre a través del "mar insano de su vida"; es un "farol que no se encubre, mas no descubre el puerto en la tormenta"; un "sol que todo ñublado desbarata"; "el más dichoso fin que se pretende". El amor es la "raíz de donde nace la venturosa planta que al cielo nos levanta" (II, 69-70). Claro que el enamorado racional tendrá que soportar los tormentos del deseo, las heridas y la enfermedad, pero su recompensa de un amor que "no tiene pago ni otra satisfacción sino el mesmo amor" será para él más satisfactoria que cualquier otro bien. El amor, en suma, trae la vida, la paz, el placer y la alegría. Y lo que quizá sea más significativo, cuando se toman en cuenta los designios de un escritor que quiere basar una narración en el amor, el amor trae una conclusión ${ }^{16}$.

${ }^{16}$ Para una exposición instructiva, aunque muy esquemática, del punto fundamental que separa a Lenio y a Tirsi en el debate de Cervantes - acerca de si "si può amar con termine" -, véase Tullia D'Aragona, Dialogo della infinità di amore. Trattati d' amore del Cinquecento, ed. G. Zonta, Bari, 1912. Nótese que Cervantes atenúa significativamente el aspecto contemplativo de los neo- 
A Tirsi se le suele considerar portavoz de Cervantes. Su visión es evidentemente muy atractiva, y no se puede negar que, en su mezcla de valores platónicos y cristianos, mira hacia adelante, hacia un humanismo cristiano que habrá de animar el gran arte ejemplar de Cervantes ${ }^{17}$. Sin embargo, es igualmente evidente que Cervantes aún no ha desarrollado un arte narrativo capaz de reflejar esa visión como una posibilidad de la vida real, y que el discurso de Tirsi, como la propia Galatea, nos da la extraña impresión de ser un centro mal colocado o no integrado de ese turbulento mundo literario. En suma, ni la visión de gozosa satifacción amorosa (en Tirsi) ni los anhelos implícitos de integridad del ser (en Galatea) tienen mucho que ver con lo que realmente ocurre en La Galatea. En esta curiosa falta de resonancia dentro de la obra, me parece que el discurso de Tirsi es muy diferente de las "razones de filosofía" de Montemayor en la Diana, que fue uno de los modelos de Cervantes. En efecto, la argumentación de León Hebreo, sobre la razón extraordinaria y el valor implícito de la irracionalidad y el sufrimiento en cualquier amor apropiado y fundado en la razón, apoya la peculiar exaltación del sufrimiento amoroso y de la intensidad emocional que encontramos a lo largo de la Diana ${ }^{18}$.

El lector no tarda mucho en sentir que el autor de La Galatea tiene una obsesión con lo interrumpido o truncado; y si conoce bien la narrativa y la teoría literaria del Renacimiento, no tarda en advertir que Cervantes está experimentando audazmente con las famosas técnicas de Heliodoro: fragmentación del argumento, suspensión por medio de la limitación del punto de vista, acia-

platónicos cuyas voces llenan esta escena, aunque parecería que una parte de la imagen de plenitud que da Tirsi procede del último libro de Gli Asolani, de Bembo, donde tanto se insiste en la trascendencia.

17 Véase Avalle-Arce, op. cit., p. 207. Los temas básicos que se plantean y no encuentran solución adecuada en el debate central de La Galatea son precisamente los que están implícitos en la concepción imaginativa del enfrentamiento de Preciosa con el mundo de los gitanos y que se encuentra en el centro de la narración más profunda y lograda de Cervantes sobre la experiencia amorosa humana. Véase mi Cervantes and the humanist vision, Princeton, 1982, cap. 2.

${ }^{18}$ Sobre el debate de amor en Montemayor y su relación con León Hebreo, véase La Diana, ed. F. López Estrada, Madrid, 1962, pp. 194 ss. Sobre la "razón extraordinaria" véase Dialoghi d'amore, ed. cit., pp. 52-58; cf. también T. Anthony Perry, Erotic spirituality: The integrative tradition from Leone Ebreo to John Donne, University of Alabama, 1980, cap. 1. 
raciones retrospectivas de hechos sorprendentes que se desarrollan ante los ojos de un lector asombrado, deslumhrado y a menudo frustrado. Algunas de las manifestaciones de esta obsesión son bastante extrañas. Vemos, por ejemplo, que se interrumpe la recitación de un soneto en el octavo verso, para terminar unas sesenta páginas más adelante. En el último libro nos encontramos con un enigma, una adivinanza en verso que dicen los pastores, cuya solución es el enigma mismo, lo cual nos atrapa en una especie de círculo vicioso: la respuesta se elude en el último momento, y se nos obliga a reiniciar la búsqueda. El enigma que concluye la serie queda sin solución, como si hubiera abortado por una de las innumerables interrupciones con que La Galatea, en forma que casi parecería programática, rompe sus momentos de irresolución.

Quizá lo que revela más notablemente esta tendencia a evitar el cumplimiento narrativo es la forma en que Cervantes trata el matrimonio, objetivo amoroso de Tirsi. Aquí resulta instructivo detenernos un momento en las ceremonias nupciales con que concluye uno de los principales modelos de Cervantes, la Diana enamorada de Gil Polo, obra que, al igual que La Galatea, saca su filosofía amorosa de los Asolani de Bembo y de sus distinciones esenciales, que se reflejan en el debate de Tirsi y Lenio sobre el amor. El último libro de la obra de Gil Polo es introducido por su narrador como un punto de reposo, un punto en que el deseo de cada uno de los pastores se ha cumplido. La energía amorosa que ha impulsado a los pastores a frenéticas persecuciones durante los cuatro primeros libros se ve contenida aquí en los movimientos ordenados de la danza, de canciones de armoniosos ecos, en la agresión estilizada de una guerra entre el impulso y la racionalidad triunfante, representada en una colorida mascarada, una serie de preguntas y la correspondiente serie de respuestas, y una secuencia de enigmas que se resuelven y revelan visiones de la ordenada composición del ser humano, los sexos y la sociedad. Pero desde nuestro punto de vista quizá el detalle más interesante de este clímax plenamente orquestado sea la sublimación estética de la frustración del pastor, con sus deseos sin esperanzas, frente a la desamorada, en un diálogo poético lírico y simétrico en el cual ésta decide callar su respuesta final por temor de turbar el espíritu de alegría que impera en la fiesta nupcial y resultar "enojosa a toda aquella compañía". En suma, en el último libro de la Diana de Gil Polo encontramos un claro punto de reposo que corrige y aun justifica los errores a partir de los cuales se había tejido la acción 
romántica de los cuatro libros anteriores, una paradisíaca condición estática donde el ritual reiterado, las canciones que se repiten como eco y los movimientos simétricos logran eliminar todo flujo y establecer el paraíso amoroso intemporal del deseo satisfecho ${ }^{19}$.

El matrimonio de Daranio y Silveria ocurre al final del libro tercero, que es el punto central de la obra en su versión actual y precede al debate entre Tirsi y Lenio. Buena parte del movimiento del argumento principal lleva a este hecho, y como la narración se ha ocupado de la actividad amorosa y sus vicisitudes, el hecho se presenta como un objetivo estructural y temático a la vez, aun para el lector que no conoce las tradiciones literarias de Montemayor y Gil Polo, que convergen en esta escena. Sin embargo, al alcanzar la meta, lo más notable es que Cervantes se aleja bruscamente del cumplimiento. El episodio dedica una atención mínima a la boda y a las posibilidades del amor conyugal, y se centra en cambio en la desgracia del mísero y cadavérico pretendiente rechazado del triángulo, antecesor del Basilio del Quijote, que habrá de ser una de las últimas variantes cómicas cervantinas sobre la obsesión pastoril de amor-muerte. En vez de centrarse en el cumplimiento, la escena de la boda intensifica la frustración. Y, lo que es más importante, la celebración ritual de la consumación que normalmente sería el clímax de la boda se ve desplazada por la "contienda lastimera" de una larguísima égloga, que por más de veinticinco páginas glosa el tema de la frustración y examina analíticamente la naturaleza distintiva del sufrimiento del amante por la muerte de la amada, su ausencia, su desdén, o los celos de un rival. Para comprender cuán cerca está este paraíso amoroso cervantino de convertirse en el tradicional infierno amoroso del deseo no consumado, basta recordar cómo Grisóstomo concentra precisamente esos cuatro sentimientos y los motivos de destrucción que están alrededor de cada uno de ellos en la "Canción desesperada" que explica su suicidio en el Quijo$t e$. Después del larguísimo fluir de "razones de amor" y las infinitas distinciones categóricas y casuísticas de su tortuoso raciocinio, el pequeño epitalamio, que canta la felicidad conyugal, las bondades del trabajo en el campo, la plenitud de la naturaleza,

19 Cf. GIl Polo, Diana enamorada, ed. R. Ferreres, Madrid, 1953, libro $\mathrm{V}$, sobre todo p. 220. Claro que habría que señalar que la obra no presta mucha atención a la manera como las personas verdaderas pueden alcanzar ese punto, ni a las complejidades ocultas tras sus oscilaciones bruscas, arbitrarias y aparentemente mecánicas entre la frustración y la realización. 
los placeres que brindan los hijos, la economía de la organización doméstica y el curso natural del ciclo vital, del nacimiento a la muerte, suena extraño, fuera de lugar, y ciertamente no aparece como el punto de reposo hacia el cual tendían la acción y la articulación temática. Como los anhelos no formulados de Galatea, como la visión de Tirsi, esta leve voz, que más parece una idea tardía que una conclusión y que nunca se vuelve a oír en la obra, aparece como una más de las insinuaciones pasajeras de los anhelos del propio Cervantes, anhelos de un ideal amoroso maduro y constructivo en el mundo incompleto de La Galatea, y prefigura lo que vendrá muchos años después. La mujer y el cuerpo aún no han encontrado un lugar en la narrativa cervantina. Es interesante ver cómo, al volver a escribirse este episodio unos treinta años más tarde - las bodas de Camacho en el Quijote-, está casi totalmente dominado por la presencia física de Sancho Panza y su mundo.

Visto en términos de problemas genéricos, el epitalamio representa, como el largo poema pastoril de Damón en el libro cuarto, sobre la consumación ética, una voz o un género pastoril ajeno o discontinuo, y como tal muestra el eclecticismo que distingue a La Galatea entre las primeras novelas pastoriles, y también el hecho de que no logra armonizar los heterogéneos paradigmas que incorpora. Si bien la mayoría de los estudiosos del género pastoril, desde los defensores de Guarini en el siglo xvi hasta los teóricos recientes, han insistido, y con razón, en el carácter fundamentalmente no ortodoxo del género ${ }^{20}$, debemos notar que la mezcla produce en este caso un contrapunto especialmente desconcertante, que muestra las tensiones implícitas en las diversas posibilidades de este género literario. Se podría decir que Cervantes está sólo a un paso de las técnicas de ruptura del Quijote ${ }^{21}$.

20 Sobre la "heterodoxia" y el carácter experimental del género pastoril en los comienzos del neo-aristotelismo, con su insistencia en la unidad, la linealidad y el carácter cerrado del argumento, así como la uniformidad de decoro en el estilo, el tono y la elaboración de los personajes, véase B. WEINBERG, A history of literary criticism in the Italian Renaissance, Chicago, 1963, cap. 21. Sobre la "mezcla" pastoril y las "ricas posibilidades" que ofrecía a los "escritores interesados en la experimentación literaria" a fines del siglo XVI, véase R. Colie, Shakespeare's living art, pp. 243-244; véase también T. ROSEN. MEYER, The green cabinet, pp. 145-167; y la presentación que hace B. LEWALSKI de la "compleja estrategia genérica" de Milton en su articulación de diversas formas pastoriles en los idilios edénicos de su epopeya, en Paradise lost and the rhetoric of literary forms, Princeton, 1985, cap. 7.

${ }^{21}$ Al final del repudio que hace Damón de la corte y de la celebración de 
Un análisis completo de los métodos de interrupción en la narrativa de Cervantes exigiría una exposición detallada de su argumento, que es complicadísimo, verdaderamente laberíntico. No es éste el momento de emprender semejante tarea, pero hay un punto fundamental al que quiero referirme, y es que la complejidad de la trama narrativa de Cervantes aumenta notablemente en los libros cuarto y quinto, o sea inmediatamente después de la atractiva oración de Tirsi sobre las posibilidades de realización y reposo en la trayectoria amorosa. Me parece que en ese punto todos los argumentos a favor de la unidad temática, del entrelazamiento ordenado y cuidadosamente matizado, de la simetría episódica y de los sistemas numerológicos unificadores son altamente discutibles. La polifonía estéticamente satisfactoria degenera en una repelente cacofonía; todos los movimientos de integración se desmoronan ante las triunfantes energías centrífugas liberadas en la proliferación de líneas argumentales ${ }^{22}$.

Como para callar a Tirsi y avalar la visión pesimista de Lenio, de un deseo infinitamente aumentado y fragmentado, y a la vez imposible de calmar, Cervantes empieza a introducir nuevos

la "pastoral bajeza/ más alta que la alteza" (II, 39), Lenio observa: "estas canciones son las de mi gusto, y no aquellas que a cada paso llegan a mis oídos, llenas de mil simples conceptos amorosos, tan mal dispuestos e intrincados, que osaré .jurar que hay algunas que ni las alcanza quien las oye, por discreto que sea, ni las entiende quien las hizo" (II, 40). La novela pastoril "convencional" de Cervantes muestra ya una conciencia de las posibilidades de conflicto entre los sistemas genéricos distintivos incluidos en el modo pastoril, precisamente los conflictos que habrá de explotar para obtener tensiones mucho más radicales en el episodio de Marcela en el Quijote (cf. infra). En la medida en que pertenece al género pastoril, la "voz extraña" del epitalamio incorpora elementos de una tradición en la línea de Teócrito y Epicuro, que habrán de encontrar su expresión más espectacular en las Soledades de Góngora (véase T. RosenMeyer, op. cit., y D. S. CARne-Ross, "Dark with excessive bright: Four ways of looking at Góngora", en Instaurations: Essays in and out of literature, Pindar to Pound, Berkeley, 1979, pp. 133-166). Hay un excelente análisis de la canción de boda de Arsinio, de la nota discordante de su retórica popular y doméstica en medio de la pastoral cortesana, y de su relación con Góngora, en M. GAYLORD RANDEL, "Reading the pastoral palimpsest: La Galatea in Góngora's Soledad Primera", Symposium, 36 (1982), 71-91. Véase también lo que dice la misma autora sobre la preocupación de Cervantes por la falta de expresividad del lenguaje en general (no sólo cierto tipo de lenguaje, como sugiero yo) en su novela pastoril, en "The language of limits and the limits of language: The crisis of poetry in La Galatea", MLN, 97 (1982), 254-271.

${ }^{22}$ Sobre las afinidades entre los argumentos ricamente entretejidos de la pastoral renacentista y la composición polifónica en la música de la época, véase J. SheArman, Mannerism, London, 1986, pp. 91-96. 
episodios a un ritmo enloquecido. El fragmento introductorio, que despierta la curiosidad y el suspenso y el deseo de aclaraciones posteriores, se ve drásticamente reducido; un fragmento sigue mecánicamente a otro; sus semejanzas hacen peligrar la coherencia que se da por la diferenciación significativa; en ciertos momentos hay convergencia o amontonamiento simultáneo de más de un fragmento dentro del movimiento del argumento principal. La coordinación de los deseos amorosos de los personajes, que lleva la curiosidad de los amantes y los lectores a develar verdades ocultas, se fragmenta; en cierta forma, los amantes se adelantan a los lectores. El texto se acerca a los límites de la legibilidad. A medida que vamos llegando al final del libro donde aparece la elocuente celebración que hace Tirsi de la unión y el reposo, la discriminación narrativa ha cedido su lugar a la repetición exacta; la repetición productora de lo estático o de la armonía (o quizá del suspenso efectivo) ha sido desplazada por una especie de repetición cuyos efectos son mecánicos, obsesivos, casi histéricos. El lector, como el amante, gira sin cesar, torturado en la rueda de Ixión del movimiento fútil y sin sentido. En suma, las cosas literalmente no van a ningún lado, y nos acercamos al punto en que don Quijote se exaspera porque la novelita pastoril de Sancho se desintegra entre las narraciones de las suertes idénticas de cada una de las trescientas cabras en su vana lucha por atravesar el Guadiana ${ }^{23}$.

${ }^{23} \mathrm{El}$ ejemplo más notable de la complicación narrativa de Cervantes y de lo pesada que resulta ésta para el lector está quizá precisamente en el final de la alabanza de la unidad que hace Tirsi. La sucesión caótica de hechos y escenas misteriosos, y de coincidencias y relaciones no explicadas, y los métodos casi indignantes del narrador al picar la curiosidad del lector y negarse a controlar la dispersión adoptando una perspectiva omnisciente serían imposibles de describir aquí (véase II, 73-86). Al final del libro, se podría esperar que el canto amebeo de los enamorados de Galatea, con sus complicados ecos y repeticiones, por lo menos trajera algún equilibrio a ese desordenado mundo de ficción. Casi treinta años después Cervantes explotará, en La Gitanilla, los complejos patrones líricos de la forma para subrayar la intensidad de un momento visionario en el movimiento de sus amantes hacia la unión, un amor racional perfecto, una visión lúcida de la amada, el reconocimiento de sus cualidades morales, y una condición de ecuanimidad espiritual que es la recompensa de ese amor. La canción de Erastro y Elicio, en cambio, está fijada en el aislamiento, la falta de libertad y los impulsos de autodestrucción de los dos enamorados; repite una vez más la expresión petrarquista y se regodea repetidamente, si no histéricamente, en la enfermedad y el sufrimiento, reprocha a la amada su crueldad y abraza el destino del enamorado, que es el de elevarse en el entusiasmo y hundirse en la frustración ante el ídolo inmóvil. 


\section{Marcela y Grisóstomo y la conclusión de LA GaLATEA}

Como lo indica la historia de Sancho, cuando Cervantes estaba escribiendo el Quïjote, unos diez o quince años después, estaba plenamente consciente del fracaso y de lo incompleto de su novela pastoril. En el escrutinio de la biblioteca de don Quijote, su crítica de la obra señala directamente las fallas en la disposición, pero sobre todo la falta de final: "propone algo y no concluye nada". Cervantes siguió aferrado a la esperanza de terminar la obra, pero evidentemente nunca lo hizo. Cabe preguntar si pudo haberlo hecho. Uno de los aspectos interesantes de la más compleja desmitificación cervantina del género pastoril, el episodio de Marcela y Grisóstomo, son sus resonancias del último libro de La Galatea. Parecería que Cervantes vuelve a tomar el género exactamente donde lo había dejado, y de hecho se puede sostener que el episodio posterior es una continuación del sexto libro, que vuelve casi inconcebible una continuación de la obra. Vista de otra manera, esta pastoral en miniatura es un verdadero final de La Galatea, un final que literalmente destruye la posibilidad de una pastoral amorosa.

Como lo han mostrado muchos estudios valiosos, la secuencia de hechos que empieza con el encuentro de don Quijote con los cabreros y termina con los deseos frustrados de Rocinante por las "hacas galicianas" tan decididas y de tan duro corazón, representa una orquestación rica, sutil, y asombrosamente totalizadora de los motivos de la pastoral tradicional ${ }^{24}$. Un movimiento narrativo que oscila entre la articulación seria de una convención y la desfiguración deflacionaria recorre todo el episodio e incluye casi todas las formas del género en una compleja red de ironías corrosivas. La visión pastoril de la comunidad y la igualdad esenciales de los seres humanos por debajo de todas las divisiones superficiales de clase es forzada literalmente a una dramatización cómica cuando don Quijote sienta a la fuerza al reticente San-

${ }^{24}$ Véase J. B. Avalle-Arce, op. cit., pp. 217-221, y "Grisóstomo y Marcela: la verdad problemática", en Deslindes cervantinos, Madrid, 1961, pp. 97 119; J. HeRrero, "Arcadia's Inferno: Cervantes' attack on pastoral", $B H S$, 55 (1978), 289-299; H. Iventosch, "Cervantes and courtly love; the Grisóstomo-Marcela episode of Don Quixote", PMLA, 89 (1974), 64-76; E. KöHLER, "Wandlungen Arkadiens: die Marcela-Episode des Don Quijote (I, 11-14)", en Esprit und Arkadische Freiheit, Frankfurt am Main, 1966, pp. 302-327; R. Poggioli, op. cit., cap. 8; L. SPITZER, "Die Frage der Heuchelei Cervantes", $Z R P h, 56$ (1936), 138-178, esp. 145-149. 
cho, su copero, a su lado en la "mesa imperial" y lo obliga a ser " una mesma cosa conmigo". La pastoral ética de integridad individual, evocada en el anhelo de Sancho por la "soledad de su rincón", se derrumba de inmediato cuando se apresura a añadir que prefiere usar su libertad pastoril frente a las formalidades, si se la conceden, para buscar el provecho material y cultivar sus funciones corporales más violentamente perentorias -estornudar, toser, mascar de prisa. Estas extrañas manipulaciones del vocabulario libresco hereditario del lector dan el tono a toda la escena, lo cual obliga a mirar a través de una lente distorsionante el mito de la Edad de Oro y los valores tradicionales implícitos en él -libertad, paz, honradez, sencillez, inocencia, justicia, amistad y comunidad; el mito del sabio pastor y su lenguaje pastoril de comunicación pura y directa; la contención de la muerte por medio del tratamiento elegiaco; el tradicional menosprecio de corte y alabanza de aldea; la armoniosa elevación y musicalidad del estilo pastoril ciceroniano, que sugiere la presencia de un orden metafísico inherente; y toda la gama de convenciones pastoriles centradas en la experiencia amorosa - el canto, la ensoñación, las inscripciones en los árboles, las pastoras desdeñosas, los pastores que sufren, el amor contemplativo y las rivalidades amorosas, sin mencionar el amplio espectro de emociones fuertes y potencialmente trastornantes implícitas en el amor, y que el género pastoril quisiera examinar y contener.

Notamos dos procedimientos fundamentales en la articulación irónica que hace Cervantes de esas convenciones: por una parte, su contrapunto narrativo presenta una secuencia de yuxtaposiciones que señalan las sorprendentes discrepancias entre realidad y literatura y nos recuerdan todas las exclusiones ocultadas por las ficciones ilusorias del género pastoril. El procedimiento se puede observar, por ejemplo, en la reacción azorada de los cabreros frente a las inspiradas palabras de don Quijote sobre la Edad de Oro, en las impertinentes funciones corporales de Sancho y en las numerosas descripciones de comida y bebida, en la mención de las realidades económicas y los trabajos del campesino, en el mal uso del español que hace continuamente el cabrero narrador, en el reconocimiento incidental de la malicia habitual de la aldea, y en las notas cómicamente discordantes de la canción nocturna del pastor, que habla de cortejo y celos -en su recuerdo de una burda lucha entre rivales aldeanos y las obscenidades y coloridas metáforas de su lenguaje popular. Ya sean crudas, cursis o absurdas, los rechazos de la protesta de Antonio frente a la desdeñosa 
Olalla: "ni te pretendo y te sirvo/ por lo de barraganía" (I, 160), además de que prefiguran en tono de farsa la historia de Crisóstomo y Marcela, evocan cómicamente innumerables afirmaciones de los decorosos pretendientes de las novelas pastoriles y muestran en una extraña luz lo espiritual de sus súplicas.

Por otra parte, Cervantes genera complejas e inquietantes ironías desde dentro del orden literario al contraponer convenciones y códigos diferentes, de una manera que revela anomalías y paradojas agazapadas dentro de ese orden. Probablemente el caso más notable de este tipo de desorden sistemático sea la metamorfosis de la pastora desdeñosa - la "desamorada" - en portavoz elocuente de un tipo de realización personal que insiste en la integridad y la casta idealidad del ser individual, en la renuncia a todo compromiso emocional trastornador con otros seres humanos, y en el ascenso contemplativo del alma a su "morada primera". Como lo ha señalado Renato Poggioli 25 en su análisis de esta escena, lo que aquí descubrimos es un ideal pastoril alterno que se conforma dentro del mundo de la pastoral amorosa, un ideal que él llama "pastoral of the self", estudiado en su periodo de mayor resonancia histórica, desde fray Luis de León hasta Rousseau. Este ideal ocupa un lugar importante en las obras de Cervantes, de la canción de Damón en La Galatea (cf. supra) a la profecía de Soldino que anuncia el desenlace culminante del Persiles ${ }^{26}$, pero para no caer en la tentación de simplificar el compromiso crítico de Cervantes con las formas y convenciones pastoriles, deberíamos notar cómo el ideal de Marcela, proclamado en presencia de un cadáver que dramáticamente revela haber alcanzado una condición de total desapego que podría recordar el ideal ético de los estoicos y la ataraxia del sabio ${ }^{27}$, es a su vez sujeto de calificación crítica por medio del narcisismo de Marcela (se contempla

${ }^{25}$ Op. cit., caps. 8 y 9.

${ }^{26}$ Cf. Obras completas, ed. A. Valbuena Prat, Madrid, 1956, pp. 1678-1679.

27 "Para poder vivir libremente escogí la soledad [ . . ] ] ni quiero ni aborrezco a nadie [...]; si de aquí [mis deseos] salen, es a contemplar la hermosura del cielo" (I, 186-188); cf. fray Luis de León: "gozar quiero del bien que debo al cielo,/ a solas, sin testigo,/ libre de amor, de celo,/ de odio, de esperanzas, de recelo"' (Poesias, ed. A. Marasso, Buenos Aires, 1946, p. 46). Véase SPITZER, art. cit., p. 148. El interés de Marcela en el ascenso de su "alma a su morada primera" por medio de la contemplación de "la hermosura del cielo", su alusión a su "natural entendimiento" y su conciencia de que "la hermosura es amable" son interesantes ejemplos de la forma en que Cervantes transforma a esta "desamorada" en portavoz de algunas de las optimistas teorías neoplatónicas de Tirsi. 
en el espejo de los arroyos), del carácter intransigente de su simplificación pastoral de las necesidades, una reducción de sí misma a la identidad pura que presupone el aniquilamiento literal de buena parte del mundo humano circundante, su falta de todo sentimiento por el otro en presencia de la víctima y, claro, su abrupta huida y su desaparición en el desierto ${ }^{28}$.

Si un ideal de la integridad del ser surge en oposición a la meta pastoril de unión perfecta con el otro, revelando a la vez el engaño implícito en la celebrada pérdida del ser en el amor, también opera un proceso semejante desde dentro del sistema literario en la articulación cervantina de ese otro gran ideal de la pastoral amorosa: la libertad. Como lo ha mostrado Erich Köhler, la escena de Cervantes se refiere a la concepción utópica - frecuentemente expresada en los mitos renacentistas sobre la Edad de Oro (v. gr., el Aminta de Tasso y la Arcadia de Sannazaro) y que se evoca oblicuamente cuando don Quijote recuerda la libertad de que gozaban las doncellas antes de la era de la caballería andantesegún la cual la libertad humana se logra plenamente en la búsqueda sin trabas del deseo amoroso y la felicidad se consigue por medio de la satisfacción amorosa. La escena opone la creencia absoluta de Grisóstomo en este ideal a la concepción de la libertad que tiene Marcela, latente en el rechazo del amor que hace la "desamorada" pero que, en su compleja elaboración en el Quijote, contradice trágicamente la "inocente libertad de arcádica", desenmascara el sueño de la Edad de Oro como una fantasía escapista, e introduce en el mundo imaginario reductivo de la pastoral el tipo de complejidad y de ambigüedad que envuelven la elección moral de cualquier persona que vive en las realidades de la sociedad y de la historia ${ }^{29}$. En uno de los momentos más sombríos de esta escena iconoclasta, el cadáver del enamorado "habla" con amarga ironía, aferrándose a una "libertad arcádica",

${ }^{28}$ Galatea rechaza la figuración que le imponen los enamorados y el narrador; Marcela, en cambio, parecería insistir en su realidad como "desamorada", dando paradójicamente a la convención literaria una validez existencial al tiempo que revela su irrealidad cuando la usan sus perseguidores, quienes graban el epitafio en piedra. En ambos casos observamos el proceso de "desmetaforización" por medio del cual Cervantes explora los problemas y las complejidades implícitos en el discurso amatorio y sus tropos convencionales.

${ }^{29}$ Véase, por ejemplo, la cuidadosa y argumentada consideración de Marcela sobre las consecuencias paradójicas que puede tener en la vida la aplicación literal de la conocida premisa neoplatónica sobre el amor: "todo lo hermoso es amable". 
que ahora sólo puede sobrevivir en las paradojas de un loco: “'Diré [... ] que es más libre el alma más rendida/ a la de Amor antigua tiranía" 30 .

Lo que quisiera subrayar aquí es la presencia del libro sexto de La Galatea en este remotísimo episodio del Quijote y el hecho de que las manipulaciones más notables de las convenciones del puro mundo literario pastoril, del tipo descubierto por Poggioli y Köhler, se pueden ver cuando Cervantes enreda la conclusión de su obra anterior. El último libro de La Galatea contiene el momento de mayor reposo dentro del movimiento frenético y disperso de su argumento y en la atmósfera de agitación creada por sus interludios líricos de frustraciones amorosas. Este momento es, claro, el de la peregrinación al cementerio del Valle de los Cipreses y la reunión ordenada de casi todos los pastores para una ceremonia conmemorativa ante la tumba de Meliso. El movimiento convergente de la narración culmina en la descripción de la belleza, armonía y configuración simétrica del paisaje del Tajo y su locus amcenus central, la identificación y celebración de la hermosura de la naturaleza, del hombre y de los cuerpos celestiales, de la comunión en el canto entre el hombre y la naturaleza, los ritos comunales ante la tumba del poeta y amante muerto, y la elegía pastoril, cantada en las resonancias y las armonías de un cuarteto de pastores, que imaginan la resurrección de Meliso entre las estrellas y afirman la presencia continuada de su espíritu benéfico dentro de la comunidad enlutada. Después de los ritos y la elegía, en el "maravilloso silencio" de la noche, la ninfa Calíope surge sobre la tumba en una visión prodigiosa y canta el largo encomio de los poetas. Su canto celebra la continuidad de una gran tradición poética cuyo origen se encuentra en Homero y que florece en la España contemporánea, ensalzando la fama duradera de los poetas, campeones de los valores heroicos de la épica y de los dulces sentimientos de la lírica, y la inmortalidad con que dota la poesía a sus súbditos.

La pastoral, una de las formas literarias más convencionales, siempre es, con sus pastores-cantantes, un acto de homenaje a la

30 "Nur die Bejahung des Todes erlaubt es, den durchschauten Wahn festzuhalten, in den sich das arkadische Ideal verwandelt hat: die Liebe als Inbegriff der Freiheit - jetzt verkehrt in den Inbegriff der Unfreiheit, die den Tod als einzige Erlösung begrüsst' (art. cit., p. 322). Aunque válido en sus lincamientos generales, el argumento de Köhler concede demasiada importancia a la felicidad del amor satisfecho y de la libertad amorosa como rasgos constitutivos del género pastoril renacentista. 
escritura y a una tradición literaria que recrea abiertamente. Como tantos poemas pastoriles, el "Canto de Calíope" de Cervantes es un ejemplo que "would not only exemplify continuity but mythologize it as an account of poetry" 31 , y su prominencia en La Galatea es una indicación que revela la visión plenamente convencional que Cervantes tiene de sí mismo como poeta en ese punto de su carrera, y también el deseo de que su primera narración se inscriba honorablemente en la tradición literaria oficial de la época. Totalmente diferente es el concepto del poeta que encontramos en el prólogo del Quijote, con su evocación irónica del locus amonus de la inspiración poética, su burla del poeta doctus y su rechazo iconoclasta de toda esa tradición que autentifica los productos de sus procedimientos de imitación ${ }^{32}$. Con la muerte de Grisóstomo y la quema de la poesía que habría inmortalizado a su amada, bien puede ser que Cervantes esté dramatizando su propia liberación frente a una concepción ajena del poeta y de la literatura y frente a un lenguaje ajeno, que evidentemente había ejercido una poderosa influencia en su imaginación ${ }^{33}$.

Sin embargo, Cervantes no permite que el momento de la asamblea pastoril ${ }^{34}$ de La Galatea estabilice su narración, y lo enmarca con los fragmentos característicos de situaciones elípticas: vanas persecuciones de los amantes, detallada descripción de sus sufrimientos, que una vez más asaltan al lector y reactivan su deseo de aclaración y reposo. El libro pasa por una secuencia de enigmas, interrumpidos por dos intentos fallidos de suicidio de pastores frustrados, y concluye con la inminente desaparición de Galatea, la "diosa" del Valle de los Cipreses, y los preparativos de los pastores para resistir por la fuerza a la invasión del extraño. Casi todos los pastores permanecen en una condición de intranquilidad y sufrimiento en sus actividades amorosas, y su hermoso mundo se tambalea al borde de la desintegración. Al haber re-

${ }^{31}$ P. ALPERs, "What is pastoral?", Critical Inquiry, 3 (1982), 437-460, especialmente p. 441.

32 Véase mi Cervantes and the mystery of lawlessness, Princeton, 1984, pp. 187. 194.

${ }^{33}$ Véanse las observaciones de M. BAKHTin sobre la forma en que la objetivación de un discurso ajeno, pero atractivo, puede constituir un proceso importante para que un autor logre la conciencia ideológica y descubra su propia voz ("Discourse in the novel", en The dialogic imagination, Austin, 1981, p. 348).

34 Véase lo que dice D. ALPER sobre la importancia de esos momentos y su carácter tradicional en la novela pastoril, en "Convening and convention in pastoral poetry", $N L H, 14$ (1983), 277-304. 
chazado su momento de máximo reposo y plenitud - una plenitud que se da más bien en la muerte que en el amor- La Galatea termina con una vigorosa reafirmación de las tensiones y ambigüedades que he intentado seguir desde su comienzo.

Con este resumen se ve inmediatamente cómo casi todos los ingredientes de la pequeña pastoral de Marcela y Grisóstomo se encuentran en la obra antecedente. Sin embargo, la peculiar rearticulación que hace de ellos Cervantes en el Quijote no se parece en nada a la técnica de alusión directa a los antecedentes generalmente considerada como rasgo definitorio de la pastoral tradicional. El procedimiento básico de Gervantes es condensar las dos mitades del último libro de La Galatea, reuniendo los momentos visionarios de la peregrinación, la elegía, la aparición maravillosa de la ninfa en el sepulcro, y la celebración de la tradición poética, con los intentos de suicidio de Galercio y Lenio, el descubrimiento en la zamarra del pastor de versos escritos por una víctima de la desesperación amorosa, la lectura de una "canción desesperada" que se ha rescatado, y la imagen de la cruel pastora sentada en una peña, encima del lugar donde yace su víctima, proclamando en los términos más claros su concepción de la libertad arcádica - "rosas son y jazmines mis cadenas, / libre nascí y en libertad me fundo" (II, 252). El resultado de este proceso de condensación es una serie de notables desplazamientos: el poeta muerto, el espíritu tutelar del Valle de los Cipreses, objeto de adoración que reúne a una comunidad en peregrinaje, es desplazado por el cadáver del pastor frustrado, literalmente muerto de amor; el espléndido monumento de mármol de su sepulcro, al lado de la tumba solitaria que se convierte en objeto de curiosidad para los que pasan, más interesados en una historia de amor que en el cumplimiento de ritos religiosos que, como a extraños que son, les parecen raros, heterodoxos y levemente ridículos; la ninfa o sacerdotisa oficiante de los ritos de homenaje es desplazada por la pastora desdeñosa; y las ceremonias, juegos y enigmas, por un inquietante debate que precipita a los imperativos de la actividad pastoril en embates que provocan su destrucción.

En la más reveladora de las reconstrucciones cervantinas de la obra antecedente, descubrimos que la elegía bucólica - con su glorificación a coro del poeta pastoril, la afirmación de su inmortalidad en su fama y la sostenida presencia inspiradora de sus versos en la comunidad que le sobrevive, su garantía de reintegración dentro del orden natural, y su visión final de la resurrección del poeta en el paraíso celestial - es desplazada por la "Canción de- 
sesperada" en la voz aislada y solitaria de una conciencia enajenada, con su evocación de espíritus infernales, su cacofonía voluntaria, su celebración de la fragmentación y el aniquilamiento del ser y su formulación poética engañosa y egoísta de las realidades de la relación entre hombre y mujer.

En el clímax del complejo y sistemático trastorno cervantino de la pastoral, Marcela desaparece en el desierto como si fuera el producto de una imaginación enferma, y queda grabado en la piedra un epitafio que rememora los estragos que causó, en forma que poco tiene que ver con la realidad. El pasaje nos deja una fuerte sensación de la naturaleza solipsista del amor de Crisóstomo, de lo vacío de la poesía amorosa petrarquista - que conmemora ídolos generados por sí mismos y que, en el fragmento que se salva de las llamas, al igual que el mentiroso texto de piedra que sella el cadáver, sobrevive para perpetuar un engaño- y de la naturaleza ilusoria del tradicional esfuerzo pastoril por afirmar la continuidad de la vida, la naturaleza y la muerte. $\mathrm{Si}$, como lo ha dicho Erwin Panofsky, el duro hecho de la muerte parece disolverse, en Arcadia, en una bruma de sentimiento elegíaco y melancólico, Grisóstomo, en su "Canción desesperada", afirmaría que en su mundo arcádico no puede haber continuidad ni resurrección; no queda nada, salvo la muerte y la desintegración ${ }^{35}$. Resulta que la muerte es la sustancia misma de Arcadia y la pesadilla del amor arcádico.

Así pues, el episodio de Marcela y Grisóstomo permite que las tensiones que a veces inquietan la pastoral amatoria de Cervantes, reafirmándose con más fuerza por su falta de conclusión, estallen y encuentren una solución definitiva. Con la muerte de Grisóstomo y la desaparición de Marcela, Cervantes ha terminado literalmente su nueva Galatea y, con ella, cualquier posibilidad de una pastoral amorosa, revelando claramente la naturaleza ficticia del amor y del objeto amoroso que la animan, y lo vacío de la tradición poética a la que rinde homenaje. El epílogo cómico del episodio - la metamorfosis del amante frustrado y la dama de duro corazón en Rocinante y las hacas gallegas que lo reciben a coces y mordiscos cuando las persigue por el hermoso prado donde don Quijote y Sancho esperan encontrar a Marcela- lleva el procedimiento de desmantelamiento a su punto final. Toda la en-

35 Véase "Et in Arcadia ego; on the conception of transcience in Poussin and Watteau", apud R. Klibansky y H. J. Platon (eds.), Philosophy and history: essays presented to Ernst Cassirer, New York, 1963, pp. 223-254. 
gañosa experiencia del amor - la fabricación de ídolos, de poemas líricos, de géneros narrativos, la imposición de sistemas mitológicos en su honor - todo eso podría existir para ocultar las realidades fisiológicas más simples y más burdas y la violencia con que los seres humanos pueden atacarse mutuamente bajo el disfraz de esos sistemas imaginativos.

\section{Sancho Panza y la pastoral más aUténtica}

Si bien la escena de Marcela y Grisóstomo señala el momento en que Cervantes se aleja de la pastoral amorosa, de. ningún modo debería considerarse como la conclusión de sus esfuerzos por escribir en este género. Su fascinación con las posibilidades de la pastoral siguió más fuerte que nunca y, aun en este ejercicio primordialmente irónico, permite una pastoral alterna, una pastoral del ser, en la aspiración de Marcela a una vida de integridad personal, libre de compromisos emocionales con otros seres humanos y dedicada al goce contemplativo de la hermosura de la naturaleza. El ideal de Marcela, como antes dije, está rodeado de condicionamientos irónicos, y debería considerarse sobre todo como parte del proceso crítico con que Cervantes cultiva inquietantes efectos de disonancia en su integración de los diferentes códigos y paradigmas del orden literario pastoril. Resulta mucho más interesante el proceso sutil por medio del cual, en su tratamiento de los cabreros, permite la formación de una verdadera pastoral en medio del elaborado proceso de "desmitologización" de la pastoral, en medio de ese proceso y, podríase decir, desafiando ese proceso. Claro que, para los cabreros, lo que don Quijote dice de edades de oro, de bondad innata del hombre, de paz, amistad, libertad, "cosas comunes", la cortesía, justicia, inocencia y comunicación pura no son sino sandeces, pero la ironía profunda del encuentro es que la conducta hospitalaria, generosa, amistosa y fraternal de esos seres "'naturales", primitivos y lingüísticamente desposeídos frente a sus huéspedes, reivindica en realidad la concepción ética del hombre en que, por así decirlo, se basan el mito y todas sus mistificaciones. Así, alrededor de la pequeña pastoral amorosa y como parte de la complicada maquinaria de subversión irónica, vemos emerger una nueva pastoral, que se aparta de la primera y afirma claramente su existencia y su validez por encima de todo descrédito irónico. Si la orden de don Quijote a Sancho, "que seas una mesma cosa conmigo", inicia el episodio 
de los cabreros con una versión burlesca del conocido sueño pastoril de la unidad de todos los hombres por debajo de todas las divisiones sociales ${ }^{36}$, nótese que el momento final de la escena es la curación de la oreja herida del caballero con una medicina hecha de hojas de romero y sal, mezcladas con la saliva de un cabrero ${ }^{37}$.

Para concluir este estudio, me gustaría seguir el desarrollo y la convergencia de los dos ideales pastoriles que surgen en medio de la devastadora reescritura cervantina de la pastoral amatoria - los ideales que podríamos llamar pastoral del ser y pastoral de la comunidad natural ideal, o de la humanidad común. Aquí hay que volver a uno de los grandes desprestigiadores de la pastoral amorosa, Sancho Panza, y admitir que para el final del Quijote se ha convertido en uno de los representantes más importantes de su autor en el campo de la tradición literaria pastoril y sus valores duraderos.

A través de toda la Primera Parte del Quijote, la relación de Sancho con la pastoral, como su relación con la novela de caballerías y sus valores, es básicamente irónica, pues su cuerpo sumamente real, sus raíces en el orden material y el mundo cotidiano de trabajo, preocupaciones económicas, alguaciles, barberos y mesones hacen que la excesiva espiritualidad y la irrealidad de esos mundos literarios sea eminentemente visible. Su historia de La Torralba (cf. supra) es un típico ejemplo de su anti-pastoralismo. Su papel entre los cabreros es básicamente irónico, cuando nos recuerda que el verdadero trabajo de los campesinos deja poco tiempo y energías para cantar dulces canciones. Cuando don Quijote desciende con entusiasmo al infierno amoroso de delicioso sufrimiento en la Sierra Morena y da rienda suelta al registro lingüístico elegiaco de las Églogas de Garcilaso y la Arcadia de Sanna-

${ }^{36}$ Véase W. EMPSON, Some versions of pastoral, New York, 1960.

${ }^{37} \mathrm{Al}$ insistir en la unidad de todos los hombres en el nivel de la vida corporal, al mostrar las funciones y los fluidos corporales tanto de manera cómica - para la parodia de "descoronación" - como en forma positiva, como manifestaciones de la unidad y la vitalidad del hombre y de su arraigo en los procesos de regeneración, y al defender el vino como fluido de la comunión secular ("-A todos nos sabe bien, bendito sea Dios - respondió Sancho"), la escena se encamina hacia la incorporación cervantina de las tradiciones y los valores carnavalescos, en la Segunda Parte, y a la forma en que desarrolla al personaje de Sancho Panza como portavoz de esos valores. Véase mi Cervantes and the mystery of lawlessness, Pp. 204-213. En cuanto a la tradición carnavalesca de libertad e igualdad, véase M. BAKHTIN, Rabelais and his world, tr. H. Iswolsky, Cambridge, MA, 1968. 
zaro, Sancho se consuela rápidamente con la consideración de que, a diferencia de Rocinante, su rucio no está obligado a obedecer las reglas generales de los enamorados y los desesperados, puesto que las experiencias de éstos ni son asunto suyo, ni de su dueño. Y, por último, recomienda con entusiasmo un "suicidio pastoril" " para don Quijote o cualquier otro que quiera apreciar y honrar como se debe la fuerte personalidad, los encantos físicos y la agresiva sexualidad de Aldonza Lorenzo ${ }^{38}$.

En la Segunda Parte, cualquier lector se percata muy pronto de que las acciones, el habla y las preocupaciones de Sancho son mucho menos fáciles de reducir a los objetivos paródicos básicos que inspiraron su concepción, de que es verdaderamente un "principal presonaje", como él mismo dice en su propio lenguaje tan individual que es un desafío, y de que Cervantes se interesa cada vez más en el mundo de Sancho como lugar alterno de valores para la moribunda orden de la caballería y para varios órdenes sociales por los que se mueven sus protagonistas. Si bien la importancia creciente de Sancho en la narración y su supuesta quijotización, proceso que da cuenta de su nuevo activismo y sus nuevos poderes de imaginación en términos de su relación con su amo, han sido bien estudiados por los cervantistas, el grado en que su ascenso refleja un retorno de su creador a la pastoral todavía no ha sido plenamente admitido. Buen número de episodios se podrían considerar en este contexto, especialmente la serie de escenas que muestran la aldea de Sancho, y que Cervantes presenta en contrapunto con la acción que se desarrolla en el palacio de los duques. Me limito a señalar el momento más importante de ese proceso, la escena en que Sancho renuncia a su cargo de gobernador. El momento, a pesar del tono de farsa de los acontecimientos anteriores, es investido por Cervantes con la solemnidad y el misterio de un momento de conversión y renacimiento espiritual. Ocurre al final de una noche de sufrimiento. Mientras amanece, Sancho está suspendido entre el sueño y la vigilia. En lo que parece ser un rito de paso, despierta, pregunta la hora y se viste lentamente, "todo sepultado en silencio". Contemplando el misterio, los cortesanos lo siguen en una procesión silenciosa

38 “ ¡Oh hideputa, qué rejo tiene, y qué voz! [ . . ] No solamente puede y debe vuestra merced hacer locuras por ella, sino que, con justo título, puede desesperarse y ahorcarse; que nadie habrá que lo sepa que no diga que hizo demasiado de bien, puesto que le lleve el diablo" (I, 312). Véase J. HerreRO, Who was Dulcinea?, New Orleans, 1985. 
del palacio al establo y, sin atreverse a decir palabra, miran cómo abraza a su único amigo verdadero, su asno, le estampa un beso de paz en la frente, y parte solemnemente hacia la libertad de sus viñas, donde puede buscar la vida pasada que, en sus propias palabras, lo resucitará "de esta muerte presente"'. Sancho está encontrando sin lugar a dudas el camino de vuelta a sí mismo y a su clase, y desechando una especie de falsa identidad que había adoptado bajo la influencia de don Quijote; pero el regreso a su ser auténtico también es el camino de vuelta a un orden natural, un camino que, en el movimiento del palacio al establo y de allí a las viñas, es una réplica del movimiento de las numerosas expresiones aristocráticas poéticas del Beatus ille de la época y su "pastoral del ser', que celebra la plenitud interior del individuo éticamente autónomo. Claro que Sancho literaliza el tema de esos poemas, y su vuelta a la "antigua libertad" de su "vida pasada", desde un estado de "subjeción" impuesto por las responsabilidades del gobierno y simbolizado por los ropajes ceremoniales de marta cebellina y las sábanas de holanda de su cama; su huida de la agitación de la guerra al reposo a la sombra de una encina en el verano; su rechazo del gobierno en favor de la jardinería, del cetro en favor de la hoz; su liberación de la "soberbia", la ambición y la ostentación del cortesano; y su retorno al asno inocente y a los placeres de "andar por el suelo con pie llano", todo ello recuerda los motivos antitéticos sobre los que se construían esos poemas. Si su reformulación de la antigua tradición clásica está hecha en un estilo claramente terrenal y popular que lo distingue de todas las manifestaciones aristocráticas, su afirmación máxima, las palabras proverbiales del humilde, inocente Job: "desnudo nací; desnudo me hallo" tienen implicaciones que van más allá de la concepción pastoril tradicional según la cual el hombre encuentra su verdadera felicidad y su destino en la simplificación de las necesidades. En la desnudez de Sancho vemos otra tradición pastoril que viene de una fuente muy distinta y que da a su ascenso - ciertamente un momento triunfal de realización de tipo secular - un aura de misterio derivada de la tradición cristiana de la pastoral, con sus imperativos de reducción y desposeimiento del ser y sus venerables misterios de nuditas sacra ${ }^{39}$. El mo-

${ }^{39} \mathrm{El}$ ejemplo más conocido de pastoral cristiana en la literatura española del Siglo de Oro es quizá lo que fray Luis de León dice del "Pastor" en Los nombres de Cristo; véase la edición de Federico de Onís, Madrid, 1966, I, pp. 125-126; también el diálogo de A. de Torquemada sobre la "perfición 
mento supremo de recuperación y afirmación del ser, en Sancho Panza, es, paradójicamente, un momento de desposeimiento del $\operatorname{ser}^{40}$.

Cervantes había vislumbrado las limitaciones de la pastoral convencional del ser en la abnegación de la estoica Marcela y su abandono de las restricciones de la sociedad en favor de la libertad en el desierto. El ideal de libertad, inocencia, sencillez y desnudez que adopta Sancho Panza es, por contraste, un ideal decididamente social. Esto se hace muy claro al continuar su proceso de desnudamiento en la escena siguiente, donde la ropa llega a significar no sólo la ceremonia y las diferencias de rango social y los privilegios de clase, sino también las diferencias religiosas y nacionales y, más fundamentalmente, la separación entre hombre y hombre.

A mi modo de ver, es ésta una de las escenas más notables del Quijote. Habiendo abandonado la sociedad oficial, revelado las corrupciones que yacen bajo su orden complejo, y experimentado la enajenación que cualquier hombre cuerdo sentiría en ella, Sancho se encuentra de pronto reintegrado en una comunidad muy diferente. Se topa con seis peregrinos que hablan lenguas que no entiende. Excesivamente caritativo como era, según Cide Hamete, les ofrece todo cuanto posee - pan y queso- y les hace entender a señas que no tiene dinero que darles. En ese momento el morisco Ricote, disfrazado de romero, lo reconoce como su "caro amigo" y "buen vecino". Sancho, sorprendido, apenas puede creer lo que ven sus ojos y, recuperándose de la sorpresa inicial, lo abraza sin darse tiempo para bajar del asno. Notamos que tras el beso de paz que Sancho le ha dado al rucio, con todas sus sugerencias de "loving kinship of man and nature that characterizes the pastoral at its best" 41 , viene su abrazo al romero. A ese abrazo espontáneo sigue un banquete rústico, en el que los participantes - varios alemanes (o quizá holandeses), un morisco y un cristiano viejo de España- van decididamente hacia un orden

de la vida pastoril", en Colloquios satíricos, NBAE, t. 7, pp. 510-521; y El Desseoso, ed. F. López Estrada, en Notas sobre la espiritualidad española de los siglos de oro, Sevilla, 1972.

40 Véase A. Forcione, "El desposeimiento del ser en la literatura renacentista: Cervantes, Gracián y los desafíos de Nemo", NRFH, 34 (1986), 654690, especialmente 673-675.

${ }^{41}$ N. FrYe, "Varieties of literary utopias", en The stubborn structure, Ithaca, 1970, pp. 109-134; esp. pp. 131-132. 
esencial que existe por debajo de todas las distinciones de nacionalidad, religión, clase y casta. Se apartan del camino real, en relación con el reciente "edicto de Su Majestad" que excluye al que no pertenece al grupo - el morisco. Dejan sus bordones; se quitan las mucetas; se "quedan en pelota", ya que el proceso de desnudamiento ha pasado de las distinciones de ritual social y de clase a las distinciones de nacionalidad y religión; se tienden en el suelo, "haciendo manteles de las yerbas", y se dan un banquete de jamón, queso y caviar - "cosas incitativas y que llaman a la sed de dos leguas". Pero "lo que más campeó en el campo de aquel banquete fueron seis botas de vino", que los peregrinos levantan a un tiempo: "todos a una levantaron los brazos y las botas en el aire; puestas las bocas en su boca, clavados los ojos en el cielo, no parecía sino que ponían en él la puntería"'. El momento de intensa comunión tiene el aire de una experiencia mística secularizada, y su repetición ritualística está marcada por un alegre canto y un responso entre risas: "De cuando en cuando juntaba alguno su mano derecha con la de Sancho, y decía: -Español y tudesqui, tuto uno: bon compaño." Adoptando el lenguaje de la comunidad, "Sancho respondía: Bon compaño, jura Di?"' (II, 449-450).

Con la exclamación en la lingua franca y su ruptura de las barreras lingüísticas oficiales, llegamos al clímax de esa superación de las divisiones que marca todo el episodio. Y, al hacerse la proclamación de hermandad y buena voluntad universales "con una risa que le duraba una hora", vemos una especie de comunicación pre-lingüística pura e intensa que, según nos parece, podría estar operando en el encuentro de don Quijote con la comunidad de cabreros ignorantes, y que podría encontrarse detrás de las aspiraciones lingüísticas que informan su visión de la Edad de Oro. Como he sostenido en otro lugar, la escena festiva tiene afinidades obvias con la tradición cultural carnavalesca y con las aspiraciones hacia una comunidad universal de hermandad características de los escritos políticos erasmianos. La reducción pastoril de la aristocrática mesa de banquetes es simultáneamente la "descoronación" carnavalesca de la epopeya de campo de batalla y las glorias de las conquistas españolas en las numerosas guerras con los enemigos de religión ("seis botellas de vino fueron lo que más campeó en el campo") ${ }^{42}$. Además, la paradójica dignidad que logra Sancho en su estado de desnudez tiene poderosas im-

42 Véase Cervantes and the mystery of lawlessness, pp. 206-207, y Cervantes and the humanist vision, pp. 166-169. 
plicaciones relacionadas con el descubrimiento y la liberación que hace Cervantes del hombre como ser novelístico o novelable, esa "degradación" a la integridad y la singularidad que es en realidad una elevación de la realidad a una esfera heroica o poética de un tipo enteramente nuevo ${ }^{43}$. Quisiera subrayar aquí que el conocimiento de sí mismo que logra Sancho, y que Cervantes celebra en la conclusión del episodio de la ínsula Barataria, está íntimamente relacionado con su descubrimiento de que el individuo libre y éticamente maduro pertenece a algo más grande que él mismo, el cuerpo de la humanidad. Al llevarnos de la sociedad falsa y altamente ritualizada del duque y la duquesa - la España oficial - a la sociedad natural y verdadera que bajo ella está soterrada, Cervantes ha encontrado el camino a una de las raíces más profundas de la tradición pastoril, su determinación de separar en términos de imaginación a la esencia de la sociedad de lo que no es esencial. Como dice Northrop Frye: "It is the feeling for what is socially essential that makes the pastoral convention central to literature" 44 . Éste es uno de los pocos tipos de pastoral al que Cervantes no pone reservas, y sospecho que para él era realmente una pastoral auténtica. En el pequeño intermedio pastoril que alegra momentáneamente las últimas páginas de Don Quijote vemos que Cervantes ha pasado del eros al ágape, de la pasión que se consume a sí misma a la amicitia, del solipsismo a la comunión, del ser a la comunidad o, digamos, a la condición esencial de pureza en que ser y comunidad son uno, en que el hombre sólo puede existir como amigo, compañero y vecino.

43 Véase mi artículo "El desposeimiento del ser...", pp. 673-675; véase también M. BAKHTIN, The dialogic imagination, tr. C. Emerson y M. Holquist, Austin, 1981, p. 40.

44 “"Varieties of literary utopias", p. 132. Véase también la descripción que hace Schiller del idilio y del modo de percepción idílico, así como su rechazo de la separación entre naturaleza y civilización que es característica del culto de Rousseau. La condición de paz y armonía del idilio "findet nicht bloss vor dem Anfange der Kultur statt, sondern er ist es auch, den die Kultur, wenn sie überall nur eine bestimmte Tendenz haben soll, als ihr letztes Ziel beabsichtet [...] wäre sie [die Idee dieses Zustandes] bloss Schimäre, so würden die Klagen derer, welche die grössere Sozietät und die Ambauung des Verstandes bloss als ein Übel verschreien und jenen verlassenen Stand der Natur für den wahren Zweck des Menschen ausgeben, vollkommen gegründet sein. Dem Menschen, der in der Kultur begriffen ist, liegt also unendlich viel daran, von der Ausführbarkeit jener Idee in der Sinnenwelt, von der möglichen Realität jenes Zustandes eine sinnliche Bekräftigung zu erhalten...' (Über naive und sentimentalische Dichtung, Werke, ed. W. Hoyer, Leipzig, 1955, t. 2, pp. 653-654. 
Hacia el final de la novela, cuando Sancho y don Quijote emprenden su melancólico regreso desde Barcelona, después de la derrota de don Quijote, qué curioso es encontrar de pronto que nuestro gran destructor de la pastoral, Sancho Panza, exhorta al moribundo don Quijote a que lo acompañe de vuelta a Arcadia, a los campos donde pueden perseguir a sus huidizas pastoras que, está convencido de ello, andan seductoramente agazapadas detrás de los matorrales familiares de la égloga. Pero, claro, vemos que su esfuerzo no está motivado por un deseo enceguecedor de satisfacción amorosa o de expansión del ser, sino simplemente por el amor y la comprensión de su buen amigo, don Quijote, y por su anhelo de mantener viva, por cualquier medio, la sociedad esencial de amistad, buena voluntad, sencillez, respeto mutuo y sueños compartidos - hasta sueños compartidos de amores imposibles-, una comunidad inocente que, junto con Rocinante y el amable rucio, han construido por esos caminos polvosos y absolutamente no arcádicos de España, caminos que, sin embargo, parecen tan alejados de la civilización y sus corrupciones como alguna vez lo fueron los de Arcadia. 